DOI https://doi.org/10.32837/app.v0i65.301

УДК 378:316.422(477)

Л. І. Кормич

ORCID ID: https://orcid.org/0000-0002-6417-862

доктор історичних наук, професор, завідувач кафедри політичних теорій

Національного університету «Одеська юридична академія»

A. I. Кормич

ORCID ID: https://orcid.org/0000-0002-2496-1186 кандидат історичних наук, доцент, доцент кафедри загальнотеоретичної юриспруденціі

Національного університету «Одеська юридична академія»

\title{
ВАРІАТИВНІ МОЖЛИВОСТІ РЕФОРМУВАННЯ ВИЩОЇ ОСВІТИ УКРАЇНИ В ЄВРОПЕЙСЬКОМУ КОНТЕКСТІ
}

Вступ. Реалізація євроінтеграційних стратегій України характеризується реформами, серед яких чільне місце займає освітня реформа. Це передусім стосується сфери вищої освіти, науковий потенціал якої продукує ідеї, стратегії розвитку та готує кадровий ресурс перспективних інноваційних процесів, забезпечуючи успіх реформ у всіх напрямах життєдіяльності суспільства. Звідси і потреба наукового аналізу змісту і способів реформування самої системи вищої освіти; надбань та прогалин в аспекті оцінки результатів змін у цій сфері, іï адаптації до освітніх стандартів СС. Саме мета узагальнення наявних розробок та окреслення пріоритетів реформативних процесів і визначила проблематику цієї статті.

Варто зазначити, що трансформація системи вищої освіти сучасної України характеризується низкою тенденцій, а саме: розширенням університетської автономії, підвищенням відповідальності за якість освіти, вдосконаленням управлінських моделей, зростанням рівня відповідності потребам ринку тощо. Зокрема, у програмних документах робиться акцент на забезпеченні фінансової та управлінської автономії закладів вищої освіти (3ВО), посиленні мотивації керівників та викладачів, орієнтації на якість та забезпечення затребуваності випускників на ринку праці (Концептуальні засади реформування, 2020). Крім того, у 2019 році відбулися суттєві зміни законодавства про вищу освіту, які в основному були спрямовані на трансформацію стандартів щодо освітніх програм та компенетностей, рівнів вищої освіти, ліцензійних умов та стандартів вищої освіти (Закон 392-IX). Прояв цих тенденцій диктується як загальним контекстом реформ в Україні, так і впливами глобалізаційних процесів, зокрема інтеграцією нашої держави в європейський освітній простір. Але динаміка суспільного розвитку постійно продукує нові тенденції або наповнює наявні новим змістом, що зумовлює пріоритетність наукового аналізу формування та функціонування освітньої сфери. У цій статті ми розглядаємо зміни в системі вищої освіти України та їх перспективність у ракурсі відповідності теорії та практики реформ новітнім тенденціям та трендам.

1. Методологічні підходи до реформування вищої освіти.

3 огляду на те, що основні напрями реформування системи вищої освіти в України нині формуються під впливом євроінтеграційних тенденцій, відповідну методологію варто розглідати саме в контексті базових ідей сучасної європейської освіти. Однією з таких ідей, безумовно, є концепт автономії універститетів, який в оригінальному вигляді, адаптованому Асоціацією університетів Європи, складається з чотирьох компонентів: (1) організаційна автономія, (2) фінансова автономія, (3) кадрова автономія та (4) академічна автономія (Estermann \& Nokkala, 2009). У різних інтерпретаціях такий перелік може включати і додаткові елементи, але вони скоріше будуть результатом подрібнення базових компонентів. Наприклад, для визначення рейтингів академічної автономії відповідно до критеріїв Асоціації університетів Свропи використовується загалом 30 окремих показників (8 показників для 
організаційної автономії, 7 - для фінансової, 8 - для кадрової, 7 - для академічної) (Pruvot \& Estermann, 2017, p. 70).

3 категорією «автономії університетів» близько пов'язана і така категорія, як «академічна свобода», оскільки остання характеризує правові та процедурні можливості та гарантії реалізації університетської автономії. Знову ж таки в рамках досліджень рівня академічної свободи в країнах $С С$ зазвичай виділяють п'ять основних ії складників: (1) академічна свобода в законодавстві, (2) інституційна автономія університетів в законодавстві, (3) самоуправління університетів у законодавстві, (4) трудові гарантії працівників університетів, (5) участь у міжнародних угодах, що гарантують академічну свободу (Karrana et al., 2017).

Таким чином, питання спроможності університетів як автономних суб'єктів освітнього процесу та наявності відповідних правових гарантій академічної свободи в університетах можна розглядати і як одну з цілей реформування вищої освіти, і як основний інструмент досягнення належного рівня української вищої освіти та ії інтеграції в європейський та світовий освітній простір.

Але такі міркування порушують низку питань щодо ступеня релевантності деяких інструментів реформування вищої освіти базовій візії сучасного автономного університету. Зокрема, це стосується проблематики ступеня деталізації та способів застосування стандартів вищої освіти, які розглядаються як засіб «для визначення та оцінювання якості вищої освіти та результатів освітньої діяльності закладів вищої освіти (наукових установ), результатів навчання за відповідними спеціальностями» (ч. 2 ст. 10 Закону про вищу освіту). Адже тут ми неминуче стикаємось із тим фактом, що концепції «автономії» та «стандартизації» в галузі вищої освіти $€$ конкуруючими за своєю сутністю і вимагають встановлення належного балансу між ними.

Цей аспект набуває додаткової актуальності (особливо для регульованих професій) 3 огляду на широке запровадження зовнішнього незалежного оцінювання студентів при вступі на магістерські програми (СФВВ, СВI). Адже зазначені випробування самі по собі представляють собою певні стандарти, оскільки фактично ставлять вимоги щодо формування під час навчання на бакалаврській програмі певного стандартизованого набору компетентностей. Отже, який інструмент є більш ефективним для забезпечення якості освіти та відповідним критеріям університетської автономії: стандартизація процесу здобуття вищої освіти, стандартизація вимог до результатів, чи обидва - питання для широкої дискусії.

До того ж, варто зазначити, що навіть у «західних» моделях проблематика оцінки якості вищої освіти викликає доволі значні суперечки щодо оптимальних форм та способів реалізації. Від часу свого виникнення на початку XX ст. вона пройшла через низку генерацій, включаючи «оцінку як вимірювання; оцінку як опис; та оцінку як судження» (Skolnik, 2010, p. 82), жодна з яких повною мірою не відповідала критеріям університетської автономії та академічної свободи. Отже, сучасна генерація оцінки якості вищої освіти має дещо інші характеристики, які роблять таке оцінювання колаборативним, а не вертикальним процесом, зокрема:

- охоплює плюралізм цінностей і починається з вимог, інтересів та проблем, висунутих усіма зацікавленими сторонами;

- використовує конструктивістську а не позитивістську парадигму;

- змінює роль оцінювача з технічного експерта або судді на медіатора та переговорника. (Skolnik, 2010, p. 82).

На наш погляд, розуміння таких характеристик сучасного процесу оцінювання якості освіти є виключно важливим для формування та впровадження всієї реформи вищої освіти в Україні. Адже досить часто перешкодою до ефективного застосування в Україні норм, правил або стандартів, що сформувалися в західних країнах, є традиції вітчизняного позитивізму у праві та публічному адмініструванні.

Особливо це стосується як раз такої категорії, як Стандарти і рекомендації щодо забезпечення якості в Свропейському просторі (ESG), оскільки такі документи є актами «м'якого права», що покликані створити певні спільні рамки, і водночас залишають дуже широку дискрецію щодо їх застосування на національному рівні. Як, наприклад, зазначається в останній редакції, ESG «не є стандартами якості чи приписами щодо втілення процесів контролю 
якості - натомість вони дають орієнтири, охоплюючи ключові аспекти успішних заходів із забезпечення якості та розвитку навчальних середовищ у вищій освіті» (ESG, 2015, p. 6).

Разом із тим у принципах ESG ми бачимо пряму вказівку на сучасне розуміння згаданої вище посередницької ролі національних інституцій, які мають опікуватися оцінкою якості вищої освіти. Адже, відповідно до принципів ESG, «вищі навчальні заклади несуть основну відповідальність за якість своїх освітніх послуг та забезпечення цієї якості», а сама «система забезпечення якості враховує потреби та очікування студентів, усіх інших залучених сторін та суспільства» (ESG, 2015, р. 8). Відповідно, базовою функцією національних органів оцінювання або забезпечення якості освіти має бути як раз узгодження інтересів всіх залучених сторін та допомога ЗВО у формуванні належних систем внутрішньої оцінки.

Це знову ж таки повертає нас до розуміння, що в центрі будь-якої реформи вищої освіти має знаходитись саме $3 \mathrm{BO} з$ його атрибутами університетської автономії та академічної свободи. При цьому цікавим аспектом, на наш погляд, $є$ те, що на практиці «виміри фінансової, організаційної та академічної самостійності не є систематично пов' язані один з одним у лінійний спосіб в Європейському контексті» (Orosz, 2018, p. 646). Єдиним винятком із цієї загальної тенденції у вищій освіті різних європейських країн $є$ помітний позитивний зв' язок між кадровою та академічною автономією, які, як правило, одночасно характеризуються або високим або низьким ступенем автономії (Orosz, 2018, p. 647).

Такі особливості дають змогу говорити про значні варіативні можливості в процесі формування політики у сфері реформування вищої освіти України.

По-перше, йдеться про можливість існування різних моделей автономії університетів, які характеризуються різними обсягами автономії окремих компонентів та різними комбінаціями компонентів із більшим або меншим ступенем автономії.

По-друге, можна розглядати можливості компенсації одних компонентів університетської автономії іншими, з огляду на забезпечення загальної спроможності ЗВО щодо виконання своєї місії. Наприклад, в українських умовах досить проблематичним може бути досягнення належного рівня фінансової автономії 3ВО, але разом із тим зростання організаційної автономії створює певний потенціал для пошуку шляхів та способів вирішення фінансових аспектів функціонування 3ВО. Таким чином, пропорційне збільшення або зменшення контролю з боку держави у певних компонентах університетської автономії може виступати ефективним інструментом державної політики у сфері вищої освіти.

Результатом такої політики має бути зростання університетського потенціалу в локальному, національному та міжнародному аспектах. Саме по собі розуміння категорії університетський потенціал асоціюється з певними внутрішніми характеристиками 3ВО, представляючи собою іманентну здатність, спроможність, внутрішній ресурс, що використовуються і можуть бути задіяні для здійснення місії закладів вищої освіти (Слюсаренко, 2015, с. 26).

Це приводить нас до важливої складової частини будь-якої політики у сфері реформи вищої освіти в Україні - пї грунтування на розумінні університету як інституції, що має власні функції, місію та ролі. При цьому інституційний підхід має охоплювати два різних прояви цієї категорії. По-перше, університет, як інституція, організує себе внутрішньо, створює певну академічну структуру, для того, щоб він міг виконувати свої функції; по-друге, університет проектує свої організовані зусилля назовні, надаючи послуги суспільству (Cabal, 1993, p. 21).

Варто зазначити, що саме розвиток організаційної та управлінської складової частини нині вважається одним із найуспішніших напрямів реформування системи вищої освіти в європейських країнах. При цьому йдеться не про якийсь стандартизований підхід, а про існування різних моделей управління, досить часто в рамках однієї національної системи вищої освіти. Більше систем проводить експерименти 3 політики в галузі організаційної автономії, що дає змогу вибраним університетам отримати більшу свободу в змінах свого управління (як в Естонії), тестуванні нових моделей призначення керівників (у Норвегії) або наданні більшій кількості установ нових правових статусів (в Португалії та Швеції) (Pruvot \& Estermann, 2018, p. 637).

Сучасна специфіка ЗВО проявляється у зв'язку організаційної стратегії та університетської автономії, бо успіх, за умов конкуренції, залежить від здатності створювати і запроваджувати 
скоординовану інституційну стратегічну поведінку щодо навчальних програм, найму персоналу, його розвитку, відбору студентів, дослідницької політики.

2. Нові моделі публічного управління та ефективне лідерство як основа сучасної реформи вищої освіти

Однією з ключових особливостей перетворень в європейських системах вищої освіти є запровадження прийомів та принципів, притаманних концепції «нового публічного управління» (New Public Management), яка являє собою «модель реформування, яка стверджує, що якість та ефективність < ..> мають бути покращені шляхом впровадження методів управління та практики, в основному з приватного сектора» (Bleiklie, 2018).

У деяких випадках йдеться про запровадження елементів більш просунутої моделі «нової публічної служби» (New Public Service), яка спрямована на вирішення таких важливих завдань:

- орієнтованість послуг на громадян;

- співвідношення ціни та якості для платників податків;

- гнучкість у наданні послуг (Bourgon, 2007).

Це не варто вважати специфікою сфери вищої освіти, а скоріше окремим випадком загальних трансформацій у сфері публічної адміністрації. У рамках таких реформ уряди намагаються підвищити ефективність сектора вищої освіти в той самий спосіб, як і в інших організаціях публічного сектора або сферах політики (Broucker \& De Witt, 2015).

Реалізація таких концепцій щодо сфери вищої освіти в європейських країнах зумовила п'ять ключових змін в управлінні 3ВО, до яких належать:

1) системна інтеграція, що охоплює різні типи інституцій, розглядаючи їх як провайдерів вищої освіти, що сприяють різними способами спільній місії в рамках спільного правового регулювання та спільних систем фінансування, оцінки та акредитації;

2) процес прийняття рішень, за якого лідери інституцій стали ближче до менеджерів та працюють разом із зовнішніми стейкхолдерами;

3) фінансування стало менш врегульованим та більш залежним від показників якості та додаткового фінансування досліджень;

4) запровадження національних агенцій з оцінки якості із збереженням сильної ролі академічних інституцій у формуванні критеріїв та процедур;

5) організація робочого процесу, що включає міжінституційну та міжнародну колаборацію тощо (Bleiklie, 2018).

Разом із тим досвід європейських країн показує існування певної специфіки впливу ідей «нового публічного управління» на ЗВО. Зокрема, це полягає в переважній участі в керівництві осіб з академічним бекграундом, ніж професійних менеджерів, що тим не менше дало змогу університетам демонструвати значну гнучкість та адаптованість на фоні кризових явищ в інших частинах публічного сектора. Це загалом свідчить про те, «наскільки ефективним може бути університетське лідерство в контексті управління більш відкритими та розподіленими освітніми установами» (Scott, 2011).

Усвідомлення академічними спільнотами на чолі з їх лідерами базових організаційних параметрів, їх спільне формування стають передумовами забезпечення ефективного організаційного розвитку закладів вищої освіти. Ключовою для керівника за таких умов є роль архітектора освітньої інституції, а ефективність ії виконання визначається рівнем володіння базовими основами теорії організаційного розвитку та здатністю ії використовувати.

При цьому проблема лідерства безпосередньо пов' язана з академічною автономією, яка на інституційному рівні проявляється у «свободі здійснення всіх стратегічних та операційних виборів та рішень, що відповідають місії університету та його ролі в суспільстві» (Noorda, 2013 , р. 3). При цьому така автономія охоплює не лише свободу створювати та впроваджувати певні стратегії або надавати послуги, але й передбачає повну відповідальність за ефективність та якість виконання 3ВО своїх функцій щодо освіти, досліджень та публічних послуг.

Згідно з підходом, адаптованим Асоціацією університетів Свропи, організаційна автономія охоплює такі аспекти, як «здатність визначати лідерську модель, склад і структуру управління, внутрішні академічні структури та можливість створення юридичних осіб» (Pruvot \& 
Estermann, 2017, p. 15). При цьому досить характерним є склад показників, що використовуються для оцінки організаційної автономії 3ВО, до якого входять:

- процедура вибору керівника;

- критерії вибору керівника;

- звільнення керівника;

- строк повноважень керівника;

- включення зовнішніх членів до керівних органів університету;

- відбір зовнішніх членів керівних органів університету;

- повноваження приймати рішення щодо академічної структури;

- повноваження створювати юридичні особи (Pruvot \& Estermann, 2017, p. 70).

Як ми бачимо, 6 з 8, тобто три чверті, показників стосуються саме порядку та критеріїв формування керівництва 3ВО, що вказує на виключне значення, яке надається саме забезпеченню ефективного лідерства у вирішенні питань внутрішньої організації ЗВО та її проекції на виконання зовнішніх функцій та ролей.

Відповідаючи на питання, як навчальні заклади можуть сприяти розвитку лідерства та організаційної спроможності, дослідники наголошують, що університети завжди брали участь у цих процесах і набули значного досвіду реалізації таких програм і політик.

Результативність наслідків змін моделі управління закладами освіти підтверджує, що тенденція до ширшої автономії зумовлює відповідні зміни в організаційних структурах, процесах управління, його професіоналізації, підвищує рівень компетентності персоналу. А вдосконалення моделі управління сприяє зміцненню всієї системи вищої освіти. Зміна моделі управління полягає в переході від централізованого адміністрування через професійний менеджмент до розподіленого лідерства. Актуалізація такого лідерства як нової управлінської парадигми зумовлюється сучасними ціннісними та організаційними тенденціями і трансформаціями, орієнтованими на довіру, відповідальність, культуру лідерства. Відповідно, пропонують розпочинати з формування усвідомлених всією академічною спільнотою відповідей на низку важливих питань, серед яких - візія університету, його місія, цілі та реальна цінність у створенні культури змін, в процесах глобального лідерства та розумінні призначення життя кожної людини в умовах сучасних викликів.

Результатом таких реформ стає нова модель розподіленого лідерства, в основі якої залучення та розподіл відповідальності серед всіх членів академічної спільноти, а не тільки управлінського персоналу. Лідерство розглядається як набір функцій, які реалізуються групою, а не як набір індивідуальних якостей і виступає як робота колективу з розвитку ефективних взаємовідносин і компетентності.

Розподілене лідерство, що базується на якості діяльності всієї команди, характеризується такими критеріями:

1) контекст, коли лідерство в меншому ступені покладається на посадові повноваження та більше на довіру до експертизи;

2) культура, в якій керівництво менше покладається на контроль та більше на повагу до досвіду та експертизи;

3) зміна, коли лідерство визнається таким, що випливає з кількох рівнів і функціонує як поєднання вертикального (згори - вниз та знизу - нагору) та горизонтального співробітництва;

4) відносини - засновані на співпраці між людьми, які разом сприяють колективній ідентичності. (Bolden at al., 2015, p. 2).

Стосовно вищої освіти потенціал цієї парадигми вбачають у змозі запропонувати нову перспективу управління, що більше відповідає сучасному освітньому простору. Ця модель передбачає переосмилення потенціалу академічної спільноти з акцентом на поєднання індивідуальної активності з активністю колективу.

Як дієві механізми реалізації розподіленого лідерства пропонується використовувати поетапний процес, який включає планування, діяльність, оцінювання, рефлексію. На кожному з них застосовуються специфічні підходи і механізми залучення людей, ïx заохочення, організації практики, оцінювання, стимулювання новаторства.

Висновки. Таким чином, взаємозалежність тапов' язаність результату зконкретнимимеханізмами реформування та їх відповідністю сучасним тенденціям і трендам єскладним і неодномірним 
процесом, що потребує зважених оцінок за цілим комплексом якісних критеріїв характеристики закономірностей та специфіки функціонування системи освіти та їі суспільної ролі.

При цьому однією з базових вимог ефективності реформи має стати довіра та залучення широкого кола академічної спільноти до їі реалізації. Адже «з багатьох моніторінгових звітів та налізів поточного стану справ ми помічаємо, що у випадку країн Східного партнерства існує постійна недовіра щодо впровадження реформ за відсутності тиску, умов або додаткових зовнішніх стимулів» (Toderas \& Stavaru, 2018, р. 717). Для формування такої довіри важливі саме якісні характеристики, а не формальні параметри оцінки такої категорії, як ефективність освітніх реформ. Якість навчання, задоволеність роботодавця, перспективи подальшого розвитку випускників, верифікованість інтересами суспільства визначають реальний внесок системи освіти в сучасний прогрес. Тому успішність реформування системи вищої освіти $\epsilon$ невід'ємною складовою частиною євроінтеграційних стратегій та перспектив демократичного розвитку України, а запровадження кращого європейського досвіду прискорює цей процес, розкриваючи нові варіативні можливості.

\section{Лimepamypa:}

Про вищу освіту : Закон України № 1556-VII. Офічіийний вісник України. 2014. № 63. Ст. 1728.

Про внесення змін до деяких законів України щодо вдосконалення освітньої діяльності у сфері вищої освіти : Закон 392-ІХ. Офіційний Вісник України. 2019. № 6. Ст. 261.

Концептуальні засади реформування публічного фінансування та управління закладами вищої освіти (2020.) Міністерство освіти і науки України. URL: https://mon.gov.ua/ua/osvita/visha-osvita/forum-vishoyi-osviti/koncepciya-reformuvannya-vishoyi-osviti.

Слюсаренко О.М. Розвиток найвищого університетського потенціалу в умовах глобалізації. Київ : Пріоритети, 2015.

Bleiklie I. (2018) New Public Management or Neoliberalism, Higher Education. J.C. Shin, P. Teixeira (eds.). Encyclopedia of International Higher Education Systems and Institutions. https://doi.org/10.1007/978-94-017-95531_143-1

Bolden R., Jones S., Davis H., Gentle P. (2015) Development and Sustaining Shared Leadership in Higher Education: Stimulus paper. London : LFHE.

Bourgon, J. (2007) Responsive, Responsible and Respected Government: Towards a New Public Administration Theory. International Review of Administrative Sciences. Vol. 73. No. 1. Pp. 726. https://doi.org/ $10.1177 / 0020852307075686$.

Broucker B., De Wit K. (2015) New Public Management in Higher Education. Huisman J., de Boer H., Dill D.D., Souto-Otero M. (eds) The Palgrave International Handbook of Higher Education Policy and Governance. Palgrave Macmillan, London. https://doi.org/10.1007/978-1-137-45617-5_4.

Cabal A.B. (1993) The University as An Institution Today: Topics for Reflection. Ottawa : IDRC. Paris : UNESCO. Estermann T., Nokkala T. University Autonomy in Europe I. Exploratory Study. Brussels : European University Association, 2009.

Karrana T., Beiterb K., Appiagyei-Atuac K. (2017) Measuring academic freedom in Europe: a criterion referenced approach. Policy Reviews in Higher Education. Vol. 1. No. 2. Pp. 209-239. http:/ / dx.doi.org/10.1080/ 23322969.2017.1307093.

Noorda S. Academic Autonomy as a Lifelong Learning Process for Universities. Leadership and Governance in Higher Education. 2013. Vol 4. Pp. 1-16.

Orosz K. (2018) Interconnected Dimensions of University Autonomy in Europe. In A. Curaj et al. (Eds.). European Higher Education Area: The Impact of Past and Future Policies. Cham: Springer. Pp. 639-649. https:/ / doi.org/ 10.1007/978-3-319-77407-7_38.

Pruvot E., Estermann T. (2017) University Autonomy in Europe III The Scorecard 2017. Brussels. European University Association.

Pruvot E., Estermann T. (2018) University Governance: Autonomy, Structures and Inclusiveness. In A. Curaj et al. (Eds.). European Higher Education Area: The Impact of Past and Future Policies. Cham: Springer. Pp. 619-638. https://doi.org/10.1007/978-3-319-77407-7_37.

Scott P. (2011) Leadership in Universities. International Journal of Leadership in Public Services. Vol. 7. No. 3. Pp. 229-234. https:// doi.org/10.1108/17479881111187051.

Skolnik M. (2010) Quality assurance in higher education as a political process. Higher Education Management and Policy. Vol. 22/1. Pp. 67-86.

Standards and Guidelines for Quality Assurance in the European Higher Education Area (ESG). (2015). Brussels, Belgium. 
Toderas N., Stavaru A.-M. (2018) The Impact of the Bologna Process on the Governance of Higher Education Systems in Eastern Partnership Countries. In A. Curaj et al. (Eds.). European Higher Education Area: The Impact of Past and Future Policies. Cham: Springer. Pp. 707-721. https://doi.org/10.1007/978-3-319-77407-7_42.

\section{References}

Bleiklie I. (2018) New Public Management or Neoliberalism, Higher Education. In J.C. Shin, P. Teixeira (eds.). Encyclopedia of International Higher Education Systems and Institutions. https://doi.org/10.1007/978-94-0179553-1_143-1.

Bolden R., Jones S., Davis H., Gentle P. (2015) Development and Sustaining Shared Leadership in Higher Education: Stimulus paper. London: LFHE.

Bourgon, J. (2007) Responsive, Responsible and Respected Government: Towards a New Public Administration Theory. International Review of Administrative Sciences. Vol. 73. No. 1. Pp. 7-26. https://doi.org/ $10.1177 / 0020852307075686$.

Broucker B., De Wit K. (2015) New Public Management in Higher Education. In: Huisman J., de Boer H., Dill D.D., Souto-Otero M. (eds) The Palgrave International Handbook of Higher Education Policy and Governance. Palgrave Macmillan, London. URL: https://doi.org/10.1007/978-1-137-45617-5_4.

Cabal A.B. (1993) The University as An Institution Today: Topics for Reflection. Ottawa: IDRC. Paris: UNESCO. Estermann T., Nokkala T. (2009) University Autonomy in Europe I. Exploratory Study. Brussels. European University Association.

Karrana T., Beiterb K., Appiagyei-Atuac K. (2017) Measuring academic freedom in Europe: a criterion referenced approach. Policy Reviews in Higher Education. Vol. 1. No. 2. Pp. 209-239. http:/ / dx.doi.org/10.1080/ 23322969.2017.1307093.

Kontseptualni zasady reformuvannia publichnoho finansuvannia ta upravlinnia zakladamy vyshchoi osvity. (2020) Ministerstvo osvity i nauky Ukrainy. URL: https://mon.gov.ua/ua/osvita/visha-osvita/forumvishoyi-osviti/koncepciya-reformuvannya-vishoyi-osviti

Noorda S. (2013) Academic Autonomy as a Lifelong Learning Process for Universities. Leadership and Governance in Higher Education. Vol. 4. Pp. 1-16.

Orosz K. (2018) Interconnected Dimensions of University Autonomy in Europe. In A. Curaj et al. (Eds.). European Higher Education Area: The Impact of Past and Future Policies. Cham: Springer. Pp. 639-649. https:/ / doi.org/ 10.1007/978-3-319-77407-7_38.

Pruvot E., Estermann T. (2017) University Autonomy in Europe III The Scorecard 2017. Brussels. European University Association.

Pruvot E., Estermann T. (2018) University Governance: Autonomy, Structures and Inclusiveness. In A. Curaj et al. (Eds.). European Higher Education Area: The Impact of Past and Future Policies. Cham: Springer. Pp. 619-638. https://doi.org/10.1007/978-3-319-77407-7_37.

Scott P. (2011) Leadership in Universities. International Journal of Leadership in Public Services. Vol. 7. No. 3. Pp. 229-234. https:// doi.org/10.1108/17479881111187051.

Skolnik M. (2010) Quality assurance in higher education as a political process. Higher Education Management and Policy. Vol. 22/1. Pp. 67-86.

Sliusarenko O.M. (2015) Rozvytok naivyshchoho universytetskoho potentsialu v umovakh hlobalizatsii. K.: Priorytety.

Standards and Guidelines for Quality Assurance in the European Higher Education Area (ESG). Brussels, Belgium, 2015.

Toderas N., Stavaru A.-M. (2018) The Impact of the Bologna Process on the Governance of Higher Education Systems in Eastern Partnership Countries. In A. Curaj et al. (Eds.). European Higher Education Area: The Impact of Past and Future Policies. Cham: Springer. Pp. 707-721. https://doi.org/10.1007/978-3-319-77407-7_42.

Zakon 1556-VII pro vyshchu osvitu 2014 (Verkhovna Rada Ukrainy) Ofitsiinyi visnyk Ukrainy. № 63. St. 1728. Zakon 392-IKh pro vnesennia zmin do deiakykh zakoniv Ukrainy shchodo vdoskonalennia osvitnoi diialnosti u sferi vyshchoi osvity 2019 (Verkhovna Rada Ukrainy) Ofitsiinyi visnyk Ukrainy. № 6. St. 261.

\section{Анотація}

Кормич Л. І., Кормич А. І. Варіативні можливості реформування вищої освіти України в європейському контексті. - Стаття.

У статті показано, що на сучасному етапі розвитку України значну роль в успіху реформ, необхідних для реалізації стратегій євроінтеграції, відіграє система вищої освіти. Функціонування цієї системи забезпечує створення теоретичних засад і формування кадрового ресурсу всієї реформаторської діяльності. Але зростання ролі вищої освіти потребує змін у самій системі. Цей процес визначається низкою тенденцій: розширенням університетської автономії, підвищенням відповідальності за якість освіти, 
вдосконаленням управлінських моделей, зростанням рівня відповідності потребам ринку тощо. Прояв цих тенденцій диктується як загальним контекстом реформ в Україні, так і впливами глобалізаційних процесів, передусім інтеграцією нашої держави в європейський освітній простір. Методологічним підгрунтям спроможності закладів вищої освіти бути невід'ємною складовою частиною суспільних реформ є сучасні концепції організаційного розвитку, успішно апробовані європейськими університетами. Вони акцентують на перспективних стратегіях, ефективному управлінні, компетентності персоналу, якості результату, використанні сучасного інструментарію. Це забезпечує баланс гуманного стилю роботи, продуктивності, економії, інновацій та ефективності, впровадженні моделей, поєднують можливості індивідуальної і колективної активності. Важливе значення для вдосконалення вищої освіти має запозичення досвіду європейських країн шляхом імплементації європейських стандартів та найкращих практик у національне освітнє законодавство, участі в різних форматах науково-дослідної та навчально-освітньої взаємодії. I разом із тим цей досвід розкриває нові варіативні можливості практики реформування, враховуючи різні моделі автономії університетів, співвідношення свободи і стандартизації, критерії оцінювання якості та інші важливі параметри, що визначають ролі та міссії закладів вищої освіти.

Ключові слова: система вищої освіти, сучасні тенденції розвитку освіти, тренди освіти, моделі та механізми реформування системи освіти.

\section{Summary}

Kormych L. I., Kormych A. I. Variable possibilities of reforming the Ukrainian higher education in the European context. - Article.

The article demonstrates that at the present stage of Ukraine's development, the higher education system plays a significant role in the success of the reforms, that is needed to implement European integration strategies. The functioning of this system ensures the creation of theoretical foundations and the formation of human resources for all reform activities. But the growing role of higher education requires changes in the system itself. This process is determined by a number of trends: the expansion of university autonomy, increasing responsibility for the quality of education, improving management models, increasing the level of compliance with market needs and more. The manifestation of these tendencies is stipulated by the general context of reforms in Ukraine, and by the influences of globalization processes, and primarily by the integration of our state into the European educational space. Modern concepts of organizational development, successfully tested by European universities, are the methodological basis for the capacity of higher education institutions to be an integral part of social reforms. They focus on promising strategies, effective management, staff competence, quality of results, use of modern tools. All this provides a balance of humane work style, productivity, economy, innovation and efficiency, implementation of models, combining opportunities for individual and collective activity. It is important for the improvement of higher education to adopt the experience of European countries through the implementation of European standards and best practices in the national educational legislation, participation in various formats of research and educational cooperation. At the same time, this experience opens up new variants of reform practice, taking into account different models of university autonomy, the relationship between freedom and standardization, quality assessment criteria and other important aspects that determine the role and mission of higher education institutions.

Key words: higher education system, modern tendencies of education development, education trends, models and mechanisms of education system reform. 